\title{
Pengaruh Tingkat Pendidikan, Jumlah Penduduk, dan Opini Audit Terhadap Transparasi Informasi Keuangan Pemerintah Daerah
}

\author{
Viona Indra Dewi ${ }^{1 *}$, Priyo Hari Adi ${ }^{2}$ \\ 1,2 Program Studi Akuntansi Fakultas Ekonomika dan Bisnis Universitas Kristen Satya Wacana
}

\section{A R T I C L E I N F O}

Article history:

Received 19 August 2019

Received in revised form

16 September 2019

Accepted 15 October 2019

Available online 30

November 2019

\section{Kata Kunci:}

Transparansi Informasi

Keuangan, Tingkat

Pendidikan, Jumlah

Penduduk, Opini Audit,

Pemerintah Daerah.

Keywords:

Transparency Of Financial

Information, Education

Level, Number of

Population, Audit Opinion

Local Government

\begin{abstract}
A B S T R A K
Transparansi informasi keuangan merupakan bentuk pertanggungjawaban pemerintah terhadap publik atas pengelolaan keuangan daerah. Tujuan dari penelitian ini yaitu untuk mengetahui faktor-faktor yang mempengaruhi transparansi informasi keuangan pemerintah daerah melalui website pemerintah daerah. Variabel yang digunakan dalam penelitian ini yaitu tingkat pendidikan, jumlah penduduk, dan opini audit. Penelitian ini menggunakan sampel 35 kabupaten/kota di Provinsi Jawa Tengah. Metode analisis data yang digunakan ialah analisis regresi linear berganda. Hasil penelitian ini menunjukkan variabel jumlah penduduk memiliki pengaruh negatif tidak signifikan, sedangkan variabel tingkat pendidikan dan opini audit memiliki pengaruh positif dan signifikan terhadap transparansi informasi keuangan pemerintah daerah di Provinsi Jawa Tengah.
\end{abstract}

\section{A B S T R A C T}

Transparency of financial information is a form of government accountability to the public over regional financial management. The purpose of this study is to determine the factors that influence the transparency of local government financial information through the local government website. The variables used in this study are education level, number of population, and audit opinion. This study uses a sample of 35 districts / cities in Central Java Province. The data analysis method used is multiple linear regression analysis. The results of this study indicate that the variable number of population has a non-significant negative effect, while the education level variable and audit opinion have a positive and significant influence on the transparency of financial information of local governments in Central Java Province.

\footnotetext{
* Corresponding author.

E-mail addresses: 232015075@student.uksw.edu (Viona Indra Dewi)
} 


\section{Pendahuluan}

Transparansi merupakan salah satu unsur penting yang wajib terpenuhi untuk terlaksananya Good Goverment Governance (Komite Nasional Kebijakan Governance, 2010). Salah satu bentuk transparasi adalah dengan penyampaian informasi keuangan daerah sehingga para stakeholder dapat memperoleh informasi mengenai pengelolaan keuangan daerah. Pemerintah dituntut untuk menyediakan informasi pengelolaan keuangan pada stakeholder secara terbuka, jujur, dan relevan. Masyarakat sebagai bagian stakeholder yang penting bagi pemerintah berhak mengetahui dan mendapatkan informasi terkait aliran penggunaan dana oleh pemerintah. Di sisi lain, pemerintah mempunyai tanggung jawab atas pengelolaan dan pelaksanaan pengelolaan keungan daerah karena setiap kegiatan yang dilaksanakan pemerintah dalam rangka menjalankan amanah masyarakat (Soepriyanto \& Aristiani, 2011).

E-government mulai diterapkan di Indonesia sejak dikeluarkannya Instruksi Presiden Republik Indonesia Nomor 3 tahun 2003 untuk pelaksanaan pemerintahan berbasis internet. E-government merupakan proses pemanfaatan teknologi informasi sebagai alat untuk membantu menjalankan sistem pemerintahan secara lebih efisien (Sosiawan, 2008). Tujuan pengembangan e-government ialah untuk meningkatkan layanan pemerintah kepada masyarakat yang dapat diakses dengan mudah dan murah dengan memanfaatkan kemajuan teknologi. Website merupakan representasi dari perkembangan egovernment yang berisi informasi berkaitan dengan daerah dan digunakan sebagai media informasi publik. PP No. 6 Tahun 2008, PP No. 3 Tahun 2007, dan Permendagri No. 7A Tahun 2007 menyebutkan secara implisit mengenai pemanfaatan media elektronik untuk mengungkapkan informasi kepada publik. Media elektronik yang disebutkan dalam beberapa peraturan tersebut dapat merujuk pada website pemerintah daerah. Instruksi Menteri Dalam Negeri (Mendagri) No. 188.52/1797/SJ/2012 tentang Transparansi Pengelolaan Anggaran Daerah (TPAD) mengamanatkan pemerintah daerah untuk menyiapkan menu content dengan nama TPAD dalam website resmi pemda.

Transparasi informasi keuangan daerah sebagai wujud dari pemerintahan yang transparan dan akuntabel dapat dilakukan dengan mengungkapkan informasi keuangannnya pada website masingmasing daerah. Di Indonesia, transparasi melalui website sudah dilakukan. Dalam penerapannya tingkat transparasi informasi keuangan bervariasi di setiap daerah mulai dari yang tergolong cukup baik hingga tidak cukup baik. Pengukuran tingkat transparasi informasi keuangan pada website dengan menggunakan Open Budget Index (OBI) menunjukkan bahwa tingkat transparasi informasi keuangan pemerintah daerah di Indonesia berbeda pada setiap daerah serta tidak ada daerah yang masuk dalam kategori cukup (sufficient) dalam keterbukaan anggaran (Halim \& Ritonga, 2017). Direktorat Jenderal Bina Keuangan dan Kementerian Dalam Negeri melakukan observasi pencapaian target Instruksi Presiden Nomor 7 tahun 2015 tentang pelaksanaan peningkatan Transparasi Pengelolaan Anggaran Daerah (TPAD) dan mendapati hasil masih terdapat daerah dengan tingkat capaian $0 \%$.

Quiles, Galera, \& Rodríguez (2014) meneliti mengenai faktor sosial ekonomi dan faktor egovernment yang mempengaruhi transparansi keuangan pemerintahan daerah di Spanyol mendapatkan hasil tingkat pendidikan berpengaruh signifikan dan positif terhadap transparasi keuangan pemerintah di Spanyol. Wau \& Ratmono (2015) melakukan penelitian terhadap faktor yang mempengaruhi Internet Financial Reporting (IFR) dengan memasukkan salah satu faktor opini audit dan diperoleh hubungan positif terhadap ketersediaan informasi keuangan di internet. Hal ini tidak sejalan dengan hasil yang diperoleh Trisnawati dan Achmad (2014) bahwa hasil audit tidak memiliki hubungan signifikan terhadap transparansi keuangan daerah melalui website resmi pemerintah daerah. Ingram (1984) menunjukkan bahwa jumlah penduduk berpengaruh positif tetapi tidak signifikan terhadap tingkat transparansi. Sedangkan Piotrowsky \& Bertelli (2010) melakukan penelitian di New Jersey mengenai transparansi keuangan pemerintah daerah dan menemukan pengaruh signifikan dan hubungan positif antara pengungkapan informasi keuangan dengan jumlah penduduk.

Penelitian ini dilaksanakan dengan tujuan untuk mengetahui faktor-faktor yang berpengaruh terhadap transparasi informasi keuangan melalui website pemerintah daerah. Pada penelitian ini menggunakan faktor- faktor yaitu tingkat pendidikan dan jumlah penduduk, opini audit. Hasil dari penelitian ini diharapkan dapat bermanfaat untuk menambah informasi dan pengetahuan di bidang keuangan daerah mengenai faktor yang mempengaruhi transparasi informasi keuangan pada website pemerintah daerah serta sebagai masukan pada pemerintah untuk meningkatkan transparasi informasi pengelolaan keuangan daerah demi terciptanya pemerintahan yang jujur dan bersih. 


\section{Metode}

Penelitian ini adalah jenis penelitian kuantitatif. Menurut Sugiyono (2005) penelitian kuantitatif bertujuan untuk membangun fakta, menguji teori, memberikan deskripsi statistik, mengetahui hubungan antar variabel, memperkirakan hasilnya. Penelitian ini bertujuan mengetahui pengaruh dan hubungan antar variabel yaitu pengaruh tingkat pendidikan, jumlah penduduk, opini audit terhadap transparasi informasi keuangan pemerintah daerah.

Populasi dari penelitian ini adalah Kabupaten dan Kota di Jawa Tengah. Teknik pengambilan sampel menggunakan purposive sampling. Pemilihan sampel yang akan digunakan dengan kriteria yaitu pemerintah daerah yang memiliki website resmi yang dapat diakses, memiliki LKPD yang sudah diaudit dan mendapatkan opini dari BPK, serta memiliki data jumlah penduduk daerah.

Penelitian ini menggunakan data sekunder yang didapat dari berbagai sumber. Tingkat pengungkapan informasi keuangan pada website didapat dari observasi peneliti pada website pemerintah daerah. Data mengenai tingkat pendidikan dan jumlah penduduk masing-masing daerah diperoleh dari situs resmi Badan Pusat Statistik (BPS). Data opini audit berasal dari opini audit yang diterbitkan BPK atas laporan keuangan pemerintah daerah pada tahun 2017.

Transparasi informasi keuangan daerah diartikan sebagai keterbukaan pemerintah kepada publik dalam membuat kebijakan keuangan sehingga kinerja pemerintah dapat diawasi oleh publik. Penelitian ini menggunakan acuan instrumen yang digunakan dalam Maksigama Indeks Keuda (Indeks Kondisi Keuangan dan Indeks Transparasi Keuangan) (2017) untuk menghitung indeks transparansi informasi keuangan masing-masing daerah. Maksigama Keuda menilai transparasi berdasarkan 3 tahapan yaitu tahap perencanaan, tahap pelaksanaan, tahap pelaporan dan pertanggungjawaban APBD. Pengukuran setiap tahapan menggunakan 29 indikator komponen keuangan yang seharusnya diungkapkan pada website pemerintah daerah. Pengukuran transparasi menggunakan empat kriteria pengukuran utama yaitu ketersediaan, keteraksesan, ketepatwaktuan pengungkapan yang diunggah dalam website.

Tabel 1. Ringkasan Operasional Variabel

\begin{tabular}{|c|c|c|c|}
\hline No & Variabel & Definisi Variabel & Operasional Variabel \\
\hline 1 & $\begin{array}{l}\text { Transparasi informasi } \\
\text { keuangan }\end{array}$ & $\begin{array}{l}\text { Transparasi informasi keuangan } \\
\text { diartikan sebagai keterbukaan } \\
\text { pemerintah kepada publik dalam } \\
\text { membuat kebijakan keuangan } \\
\text { sehingga kinerja pemerintah } \\
\text { dapat diawasi oleh publik }\end{array}$ & $\begin{array}{l}\text { Indeks transparasi keuangan } \\
\text { daerah }\end{array}$ \\
\hline 2 & Tingkat pendidikan & $\begin{array}{l}\text { Jenjang pendidikan adalah } \\
\text { tahapan pendidikan yang } \\
\text { ditetapkan berdasarkan tingkat } \\
\text { perkembangan peserta didik, } \\
\text { tujuan yang akan dicapai, dan } \\
\text { kemampuan yang dikembangkan. }\end{array}$ & Indeks lama sekolah penduduk \\
\hline 3 & Jumlah penduduk & $\begin{array}{l}\text { Penduduk merupakan jumlah } \\
\text { individu yang pada waktu } \\
\text { tertentu tinggal di suatu daerah } \\
\text { serta suatu hasil dari proses } \\
\text { demografi yang meliputi } \\
\text { kematian, kelahiran, dan migrasi }\end{array}$ & $\begin{array}{l}\text { Jumlah penduduk Kabupaten dan } \\
\text { Kota }\end{array}$ \\
\hline 4 & Opini audit & $\begin{array}{l}\text { Setiap tahun, audit atas laporan } \\
\text { keuangan pemerintah dilakukan } \\
\text { oleh Badan Pemeriksa Keuangan } \\
\text { (BPK). Dari hasil pemeriksaan } \\
\text { BPK akan memberikan empat } \\
\text { jenis opini }\end{array}$ & $\begin{array}{l}\text { Tidak memberikan pendapat : } 1 \\
\text { Tidak wajar : } 2 \\
\text { Wajar dengan pengecualian : } 3 \\
\text { Wajar tanpa pengecualian dengan } \\
\text { paragraf penjelas }: 4 \\
\text { Wajar tanpa pengecualian : } 5\end{array}$ \\
\hline
\end{tabular}

Penelitian ini diawali dengan pengumpulan data dari masing-masing variabel independen dan variabel dependen selanjutnya dianalisis dengan regresi berganda untuk melihat signifikansi hubungan antara transparasi informasi keuangan dengan tingkat pendidikan, usia pemerintah daerah, dan opini audit. Uji regresi berganda digunakan karena dalam penelitian ini menggunakan satu variabel terikat dan lebih dari satu variabel bebas. Model regresi berganda pada penelitian ini sebelumnya dipastikan sudah 
lolos uji asumsi klasik yaitu normalitas, heterokedasitas, dan multikolinearitas. Berikut model regresi berganda yang digunakan :

$$
Y=\alpha+\beta 1 E D U+\beta 2 P O P+\beta 4 A U D I T+e
$$

Dimana :

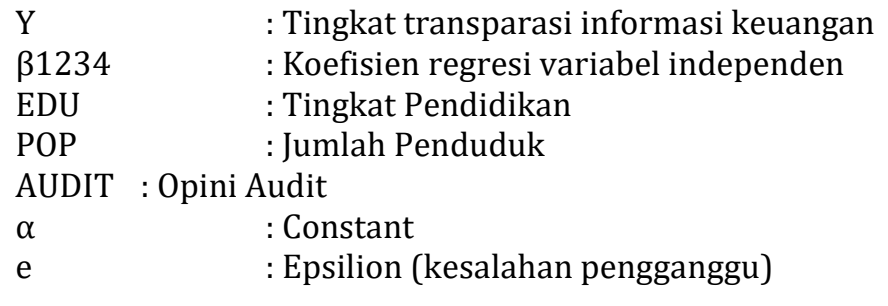

\section{Hasil dan pembahasan}

Deskripsi Objek Penelitian

Penelitian ini menggunakan 35 sampel Kabupaten dan Kota di Jawa Tengah. Jumlah website pemerintah daerah di Jawa Tengah terdapat 35 website yang keselurahan website dapat diakses. Berikut hasil pengambilan sampel dan observasi website pemda di Jawa Tengah terkait dengan transparansi informasi keuangan.

Tabel 2. Hasil Pengambilan Sampel

\begin{tabular}{ll}
\hline Kriteria Sampel & Jumlah \\
\hline Jumlah kabupaten/kota di Jawa Tengah & 35 \\
Website pemda yang dapat diakses & 35 \\
Daerah yang memiliki data jumlah penduduk, tingkat pendidikan dan opini audit tahun & 35 \\
2017 &
\end{tabular}

Jumlah sampel penelitian

35

Statistik Deskriptif Variabel Penelitian

Pada penelitian ini memuat tiga variabel yaitu tingkat pendidikan, jumlah penduduk, dan opini audit terhadap transparansi informasi keuangan pada website. Berikut ini akan dijabarkan statistik deskriptif dari masing-masing variabel.

Tabel 3. Statistik Deskriptif Variabel

\begin{tabular}{lcllll}
\hline Variabel & N & Min. & Max. & Rata-rata & SD \\
\hline Transparansi Informasi Keuangan & 35 & 7,03 & 42,97 & 22,86 & 11,01 \\
Tingkat Pendidikan & 35 & 6,18 & 10,50 & 8,20 & 1,47 \\
Jumlah Penduduk & 35 & 129.638 & 1.904 .749 & $1.031 .964,86$ & $443.761,45$ \\
Opini Audit & 35 & 3,00 & 5,00 & 4,54 & 0,85 \\
\hline & & & \multicolumn{3}{c}{ Sumber : Data sekunder yang diolah (2019) }
\end{tabular}

Statistik deskriptif dari variabel dependen dan independen dapat dilihat pada tabel 4. Hasil statistik deskriptif dengan menggunakan 35 sampel kabupaten dan kota di Jawa Tengah menunjukkan indeks transparansi informasi keuangan tertinggi yaitu 42,97 dan terendah yaitu 7,03. Daerah dengan indeks transparansi tertinggi adalah Kabupaten Magelang dan indeks transparansi terendah diraih oleh Kabupaten Banjarnegara. Rata-rata indeks transparansi informasi keuangan adalah 22,86. Terdapat 16 kabupaten dan 1 kota dengan tingkat transparansi dibawah rata-rata indeks. Hal ini mengindikasikan bahwa pemerintah daerah kota lebih transparan dibandingkan dengan daerah kabupaten. Standar deviasi untuk transparansi informasi keuangan sebesar 11,01. Hal ini menunjukkan bahwa setiap kabupaten dan kota memiliki besaran tingkat transparansi informasi keuangan yang beragam. Terdapat kesenjangan tingkat transparansi informasi keuangan antar daerah dilihat dari rentang nilai tertinggi dan terendah 
yang cukup jauh. Terdapat pemda yang sadar akan pentingnya transparansi informasi keuangan sehingga banyak mempublikasikan informasi keungannya. Ada pula pemda yang hanya sedikit menyajikan informasi keuangannya dalam website nya.

Nilai tingkat pendidikan tertinggi dimiliki oleh Kota Semarang yaitu sebesar 10,50. Nilai tingkat pendidikan terendah yaitu 6,18 pada Kabupaten Brebes. Rata-rata nilai tingkat pendidikan adalah 8,20. Standar deviasi sebesar 1,47 menunjukkan bahwa nilai maksimum dan minimum tidak jauh dari nilai rata-rata. Hal ini memiliki arti bahwa tingkat pendidikan masyarakat memiliki kesenjangan yang kecil. Rata- rata tingkat pendidikan masyarakat yang tinggi menggambarkan rata-rata lama sekolah masyarakat yang tinggi pula.

Jumlah penduduk terbanyak dimiliki oleh kabupaten Brebes sebesar 1.904.749 dan kota Magelang dengan jumlah penduduk terendah sebesar 129.638. Rata-rata jumlah penduduk di provinsi Jawa Tengah yaitu 1.031.964,86. Standar deviasi untuk jumlah penduduk adalah 443.761,45 menunjukkan bahwa terdapat perbedaan jumlah penduduk antar daerah yang cukup besar. Daerah kota memiliki jumlah penduduk yang lebih sedikit dibandingkan kabupaten karena pada umumnya daerah kota memiliki luas wilayah yang lebih kecil.

Nilai opini audit tertinggi adalah 5 dan nilai terendah adalah 3. Nilai 5 mempunyai arti bahwa laporan keuangan pemda mendapat opini wajar tanpa pengecualian yang didapatkan oleh 27 daerah. Nilai 3 mempunyai arti bahwa laporan keuangan pemda mendapat opini wajar dengan pengecualian yang didapatkan oleh 8 daerah. Rata-rata nilai opini audit adalah 4,54 dengan standar deviasi sebesar 0,85. Hal ini mengindikasikan bahwa sebagian besar daerah di Jawa Tengah sudah membuat laporan keuangannya sesuai dengan prinsip akuntansi yang berlaku dan tidak ada kesalahan yang material.

\section{Uji Asumsi Klasik}

Uji normalitas digunakan untuk mengetahui apakah model regresi, variabel pengganggu, atau residual mempunyai distribusi normal. Penelitian ini untuk menguji normalitas data menggunakan uji statistik Kolmogorov-Smirnov. Apabila nilai signifikansi atau nilai Asymp. Sig (2-tailed) bernilai lebih dari 0,05 berarti residual terdistribusi normal. Hasil uji Kolmogorov-Smirnov menunjukkan nilai KolmogorovSmirnov sebesar 0,133 serta nilai signifikansi yaitu 0,123 yang lebih besar dari 0,005. Hal tersebut memiliki arti bahwa nilai residual terdistribusi secara normal dan memenuhi asumsi klasik normalitas.

Uji heteroskedastisitas digunakan untuk mengetahui apakah dalam model regresi yang digunakan dalam penelitian terjadi ketidaksamaan variance dari residual satu pengamatan ke pengamatan lain. Pengujian heteroskedastisitas dalam penelitian ini menggunakan analisis grafik scatterplot. Apabila persebaran titik dalam grafik scatterplot tidak berkumpul diatas atau dibawah, tidak membentuk pola yang jelas maka tidak terjadi heteroskedastisitas. Hasil uji heteroskedastisitas menggunakan grafik Scatterplot penelitian ini memiliki persebaran titik data berada dibawah dan diatas titik nol serta titiktitik tidak membentuk pola yang jelas. Dapat disimpulkan bahwa model regresi pada penelitian ini lolos uji heteroskedastisitas.

Uji Multikolinearitas digunakan untuk mengetahui apakah di dalam model regresi terdapat kolerasi antar variabel bebas (independen). Apabila hasil uji multikolinearitas menunjukkan nilai Variance Inflation Vactor (VIF) $<10,0$ dan nilai Tolerance $>0,10$ maka tidak terjadi multikolinearitas dalam model regresi. Model regresi yang baik yaitu model regresi yang tidak terjadi gejala multikolinearitas atau tidak memiliki kolerasi antar variabel bebas. Hasil uji multikolinearitas menunjukkan bahwa variabel tingkat pendidikan, jumlah penduduk dan opini audit mempunyai nilai VIF kurang dari 10,0 dan nilai Tolerance lebih dari 0,10. Hal ini menunjukkan bahwa model regresi penelitian ini lolos uji multikolinearitas.

\section{Pengujian Hipotesis}

Pengujian hipotesis dilakukan dengan uji regresi berganda guna mengetahui seberapa besar pengaruh variabel besbas terhadap variabel terikat. Pada penelitian ini pengujian hipotesis dilakukan untuk mengetahui pengaruh variabel tingkat pendidikan, jumlah penduduk, dan opini audit terhadap transparansi informasi keuangan pada website pemerintah daerah. Berikut hasil dari pengujian hipotesis.

Tabel 4. Hasil Pengujian Hipotesis

\begin{tabular}{|c|c|c|c|c|}
\hline \multirow[t]{2}{*}{ Variabel } & \multirow[t]{2}{*}{$\mathrm{T}$} & \multirow[t]{2}{*}{ sig } & Standarized Coefficients & \multirow[t]{2}{*}{ Keterangan } \\
\hline & & & Beta & \\
\hline Tingkat Pendidikan & 2,16 & 0,04 & 0,36 & H1 diterima \\
\hline Jumlah Penduduk & $-0,20$ & 0,85 & $-0,03$ & H2 ditolak \\
\hline Opini Audit & 2,33 & 0,03 & 0,36 & H3 diterima \\
\hline $\operatorname{Adj} \mathbf{R}^{2}$ & & 0,29 & & \\
\hline
\end{tabular}


Sumber : Data sekunder diolah (2019)

Koefisien determinasi $\left(\mathrm{R}^{2}\right)$ digunakan untuk mengetahui seberapa besar variabilitas variabel independen dalam menerangkan variabel dependen. Nilai Adjusted $R$ Square diperoleh sebesar 0,29. Hal ini berarti bahwa 29 persen variasi transparansi informasi keuangan dapat dijelaskan oleh ketiga variabel sedangkan sisanya 71 persen dijelaskan oleh variabel lain yang tidak diuji dalam model ini.

Setelah dilakukan analisis regresi berganda diketahui bahwa tingkat pendidikan memiliki pengaruh positif yang signifikan terhadap transparansi informasi keuangan pada website pemda. Hal ini terbukti dari nilai $t$ hitung 2,16 dan nilai signifikansi 0,04 $<0,05$ sehingga dapat disimpulkan bahwa H1 yang menyatakan bahwa tingkat pendidikan berpengaruh positif terhadap transparansi informasi keuangan pada website pemda dapat diterima.

Jumlah penduduk memiliki pengaruh negatif tidak signifikan terhadap transparansi informasi keuangan pada website pemda. Kesimpulan tersebut didapatkan dari thitung yang memiliki nilai $-0,20$ dan signifikansi dengan nilai $0,85>0,05$. Hal tersebut membuktikan bahwa hipotesis kedua yang menyatakan bahwa jumlah penduduk berpengaruh positif terhadap transparansi informasi keuangan pada website pemda ditolak.

Pengaruh opini audit terhadap transparansi informasi keuangan pada website pemda dapat diterima memiliki hasil positif signifikan. Kesimpulan tersebut diperoleh dari nilai t hitung sebesar 2,33 serta nilai signifikansi $0,03<0,05$ sehingga hipotesis lima yang menyatakan bahwa opini audit berpengaruh positif terhadap transparansi informasi keuangan pada website pemda dapat diterima.

Pengaruh Tingkat Pendidikan terhadap Transparasi Informasi Keuangan Pemerintah Daerah

Dalam hasil penelitian ini menunjukkan adanya pengaruh positif signifikan tingkat pendidikan terhadap transparansi informasi keuangan pada website pemda. Temuan ini didukung oleh Gandia (2008) dalam penelitiannya di Spanyol mendapatkan hasil penelitian tingkat pendidikan memiliki pengaruh signifikan positif pada tingkat transparasi keuangan pemerintahan lokal. Tolbert, Mossberger, \& McNeal (2008) dalam risetnya menemukan adanya hubungan antara permintaan terhadap informasi kepada pemerintah terhadap tingkat pendidikan masyarakat.

Taraf pendidikan masyarakat mampu mendorong penguatan transparansi informasi keuangan pemerintah daerah. Masyarakat harus mengenal pendidikan dan bersahabat dengan pendidikan karena pendidikan merupakan modal utama masyarakat untuk memainkan perannya sebagai stakeholder yang berhak untuk mengetahui pengelolaan pemerintahan daerahnya. Peningkatan tingkat pendidikan masyarakat akan menggerakan partisipasi masyarakat dalam upaya bottom-up reforms dengan jalan memicu peningkatan pengawasan dan kontrol sosial terhadap kinerja pemerintah. Dengan rata-rata tingkat pendidikan masyarakat Jawa Tengah yang cukup tinggi mengindikasikan bahwa masyarakat mampu menggunakan internet sebagai sarana mencari informasi kinerja pemerintah. Salah satu media yang dimiliki pemda untuk penyampaian informasi di internet yaitu website pemda. Pendidikan yang memadai mendukung masyarakat dalam penggunaan internet dan memahami informasi keuangan yang disajikan pemerintah daerah dalam website.

Pengaruh Jumlah Penduduk terhadap Transparansi Informasi Keuangan Pemerintah Daerah

Jumlah penduduk berpengaruh negatif namun tidak signifikan terhadap transparansi informasi keuangan pada website pemda. Hal ini menunjukkan bahwa besarnya jumlah penduduk bukan faktor yang mendorong pemerintah daerah untuk melakukan transparansi informasi keuangan pada website. Jumlah penduduk suatu daerah menggambarkan kompleksitas dari suatu pemerintahan daerah. Besarnya jumlah penduduk mencerminkan besarnya layanan kebutuhan masyarakat yang harus disediakan oleh pemerintah. Hal ini akan membuat bertambahnya pekerjaan pemerintah yang mengakibatkan informasi yang harus disajikan pemerintah untuk transparansi informasi keuangan semakin banyak. Kompleksitas ini justru menghambat pemerintah dalam melakukan transparansi. Pemerintah tidak terdorong untuk melakukan transparansi yang merupakan bentuk tanggungjawab dan akuntabilitas kinerja pengelolaan keuangannya.

Penelitian ini sejalan dengan penelitian Hasanah (2016) yaitu jumlah penduduk berpengaruh secara negatif dan tidak signifikan terhadap publikasi informasi keuangan di website. Selain itu, temuan penelitian ini didukung oleh Afryansyah \& Haryanto (2013) yang menemukan besarnya jumlah penduduk tidak mempengaruhi pemerintah untuk mempublikasikan informasi akuntansinya di internet. 
Pengaruh Opini Audit terhadap Transparansi Informasi Keuangan Pemerintah Daerah

Hasil pengujian hipotesis pada opini audit menunjukkan pengaruh positif serta signifikan terhadap transparansi informasi keuangan pemda. Hal ini menandakan bahwa semakin besar nilai opini audit maka semakin besar pula tingkat transparansi informasi keuangan pemda. Hal ini sejalan dengan penelitian Wulandari dan Sulardi (2018) menemukan bahwa opini audit mempengaruhi publikasi informasi keuangan secara wajib dan secara sukarela. Penelitian ini juga konsisten serupa dengan Wau \& Ratmono (2015) yang memperoleh hasil opini audit berpengaruh terhadap ketersediaan informasi keuangan pemerintah di internet. Hasil penelintian ini juga didukung oleh Styles \& Tennyson (2007) yang menyatakan bahwa pemerintah daerah yang mendapatkan penghargaan atas praktek pelaporan keuangan yang baik oleh organisasi eksternal, maka pemda tersebut cenderung mempublikasikan laporan keuangannya di internet.

Opini audit mampu mendorong pemerintah untuk melakukan transparansi informasi keuangan. Laporan keuangan yang mendapatkan opini yang baik dari BPK mengindikasikan akuntabilitas dan kinerja suatu pemerintah daerah baik. Berdasarkan hasil statistik deskriptif, rata-rata kabupaten dan kota di Jawa Tengah mendapatkan dua jenis opini yaitu wajar tanpa pengecualian dan wajar dengan pengecualian. Hal tersebut membuat pemda cenderung tidak akan menutup-nutupi hasil dari kinerjanya yang baik kepada masyarakat. Pemda yang mempublikasikan informasi keuangan dengan opini bagus akan menaikkan citra baik pemda tersebut serta menandakan bahwa pemda telah melaksanakan jalannya pemerintahan secara bersih dan bertanggungjawab.

\section{Simpulan dan saran}

Berdasarkan hasil penelitian dan analisis pembahasan yang telah dilakukan dalam penelitian ini, maka dapat disimpulkan bahwa tingkat pendidikan memiliki pengaruh positif signifikan. Hal ini menunjukkan bahwa semakin tinggi pendidikan masyarakat, maka akan mendorong peningkatan transparansi informasi keuangan karena pendidikan merupakan modal masyarakat dalam memahami informasi keuangan yang disajikan pemerintah daerah dalam website. Opini audit memiliki pengaruh positif signifikan terhadap transparansi informasi keuangan. Hal ini menunjukkan bahwa semakin baik opini audit yang diterima pemda maka akan mendorong pemda untuk mempublikasikan informasi keuangannya guna menunjukkan pada masyarakat kinerja keuangan pemerintah yang baik dan maikkan citra pemerintah. Jumlah penduduk berpengaruh negatif tidak signifikan terhadap transparansi informasi keuangan pemerintah daerah. Hal ini membuktikan bahwa besarnya jumlah penduduk bukan faktor yang mendorong transparansi informasi keuangan sebab besarnya jumlah penduduk akan menambah kompleksitas pemerintahan yang mengahambat transparansi informasi keuangan.

Dalam melakukan penelitian ini memiliki keterbatasan dalam akses informasi keuangan yang tersedia dalam website. Terdapat beberapa website pemda menyediakan menu indikator informasi yang dibutuhkan dalam penilaian transparansi namun mengharuskan pengunjung website untuk mendaftar dan mengirim permintaan informasi yang dibutuhkan. Beberapa website pemda tidak dapat digunakan untuk mendaftar atau login dan tidak adanya tanggapan setelah melakukan permintaan informasi.

Saran yang bisa penulis berikan yaitu bagi pemerintah diharapkan dapat memperbaiki sistem pendaftaran atau login pada website serta lebih cepat tanggap dalam merespon permintaan informasi. Penelitian selanjutnya dapat menggunakan sarana selain website dalam menilai transparansi informasi keuangan pemerintah seperti aplikasi ponsel PPID. Saran terkait dengan hasil penelitian ini yaitu pemerintah dapat melakukan usaha meningkatkan pendidikan masyarakat karene pendidikan merupakan modal yang penting bagi masyarakat untuk berpartisipasi dalam pengawasan kinerja pemerintah. Selain itu pemerintah juga diharapkan dapat meningkatkan kinerja keuangannya agar mendapat opini audit yang baik sehingga membuat masyarakat percaya bahwa pemerintah melaksanakan kinerja pengelolaan keuangan dengan baik.

\section{Daftar Rujukan}

Afryansyah, R. D., \& Haryanto. (2013). Faktor-Faktor Yang Mempengaruhi Pengungkapan Informasi Akuntansi Di Internet Oleh Pemerintah Daerah. Diponegoro Journal Of Accounting, 2(3), 1.

Evans, D., \& Yen, D. C. (2005). E-government: An analysis for implementation: Framework for understanding cultural and social impact. A.G.I.M Office, 29-41.

Evans, J., \& Patton, J. (1987). Signalling and Monitoring in Public Sector Accounting. Journal of Accounting Research 25 (Supplement), 130-158. 
Gandia, J. L. (2008). Determinants of web site information by Spanish city councils. Online Information Review, 35-57.

Garcia, \& Garcia, G. (2010). Determinants Of Online Reporting Of Accounting Information by Spanish Local Government Authorities. Local Government Studies, 36(5), 679-695.

Halim, A., \& Ritonga, I. T. (2017). Maksigama Indeks Keuda (Indeks Kondisi Keuangan dan Indeks Transparasi Keuangan). Yogyakarta: Pustaka Pelajar.

Hasanah, U. (2016). Faktor-Faktor Yang Memengaruhi Publikasi Informasi Keuangan Pemerintah Daerah Melalui Internet. JAI.

Ingram, R. W. (1984). Economics Incentives and the Choice of StateGovernment Accounting Practices. Journal of Accounting Research, Vol. 22(No. 1), 126-144.

Komite Nasional Kebijakan Governance. (2010). Pedoman Umum Good Public Governance.

Mardiasmo. (2001). Pengawasan, Pengendalian dan Pemeriksaan Kinerja Pemerintah Daerah dalam Pelaksanaan Otonomi Daerah. Yogyakarta: Andi.

Martani, D., Nastiti, D., \& Wicaksono, P. T. (2014). Disclosure Of Non-Financial Information About Public Services On The Official Website Of Local Governments In Indonesia. Journal of Theoretical and Applied Information Technology, 66 No 2.

Piotrowsky, S. J., \& Bertelli, A. (2010). Measuring Municipal Transparency. 14th IRSPM Conference, Bern, Switzerland, April.

Quiles, F. A., Galera, A. N., \& Rodríguez, D. O. (2014). Factors influencing the transparency of sustainability information in regional governments: an empirical study. Journal of Cleaner Production 82, 179191.

Said, R. (2001). Pengantar Ilmu kependudukan. Jakarta: Lembaga Penelitian dan Pembangunan Ekonomi dan Sosial.

Soepriyanto, G., \& Aristiani, R. (2011). Evalusi Pengungkapan Laporan Keuangan Daerah Di Situs Internet: Studi Pada Pemerintah Daerah Indonesia. Binus Business Review, Vol. 2(No. 1 ), 192-201.

Sosiawan, E. A. (2008). Tantangan dan Hambatan Dalam Implementasi E-Government di Indonesia. Seminar Nasional Informatika 2008, 99-108.

Styles, A., \& Tennyson, M. (2007). The Accesibility of Financial Reporting U.S Municipalities on The Internet. Journal Of Public Budgeting, Accounting and Financial Management, 19(1), 56-92.

Sudarsana, S. H. (2013). Pengaruh Karakteristik Pemerintah Daerah dan Temuan Audit BPK Terhadap Kinerja Pemerintah Daerah. Diponegoro Journal of Accounting, 2(4), 1-13.

Sugiyono. (2005). Metode Penelitian Administrasi. Bandung: Alfabeta.

Suryaningsih, N. M., \& Sisdyani, E. A. (2016). Karakteristik Pemerintah Daerah dan Opini Audit Pada Kinerja Keuangan Pemerintah Daerah. E-Jurnal Akuntansi Universitas Udayana, 15(2), 1453-1481.

Tolbert, C. J., Mossberger, K., \& McNeal, R. S. (2008). Institutions, policy and e-government. Public Adminisration Review, 68, 549-563.

Trisnawati, M. D., \& Achmad, K. (2014). Determinan Publikasi Laporan Keuangan Pemerintah Daerah Melalui Internet. 
Wau, I., \& Ratmono. (2015). Analisis Faktor-Faktor Yang Mempengaruhi Ketersediaan Dan Keteraksesan Internet Financial Reporting Oleh Pemerintah Daerah. Diponegoro Journal Of Accounting, 4(4), 112.

Wulandari, N. A., \& Sulardi. (2018). Pengaruh Karakteristik Daerah, Temuan, Dan Opini Audit Terhadap Pengungkapan Sukarela. Akuntansi Dewantara, 2(1).. 